\title{
Prognostic index for myocardial infarction treated in a coronary care unit
}

\author{
B. L. Chapman ${ }^{1}$ and C. H. Gray
}

From the Department of Medicine, The Royal Newcastle Hospital, Newcastle, N.S.W.; and Division of Computing Research, Commonwealth Scientific and Industrial Research Organization, Sydney, N.S.W., Australia

A prognostic index for patients with acute myocardial infarction treated in a coronary care unit was presented. It was derived by multiple regression analysis, and was based on the only three factors, of the many examined, that made significant independent contributions to the outcome. These were the serum aspartic aminotransferase (SGOT) level, cardiogenic shock, and oliguria. The system of scoring was simple, especially with a readyreckoner which was provided. There was very good agreement between the coronary prognostic index and the observed mortality rate, and there was a highly significant linear correlation between the two $(r=0.986$, $P<0.0002)$. Ninety-seven per cent of the variation in mortality rate was explained by variation in the prognostic index. The numerical values of the index, moreover, were close approximations of the mortality rate, and could, therefore, be used to predict this.

The results supported the hypothesis that, in cases treated in a coronary care unit, the cardiac complications of acute myocardial infarction are only indirectly related to the mortality rate, their presence merely reflecting the extent of infarction. Cardiogenic shock was an exception, but other authors have shown that this complication may lead to an extension of the original infarct. It was now further suggested that the independent contribution of oliguria to the outcome may be the result of secondary ischaemic damage in an important extracardiac organ.

In order to assess the comparability of cases of acute myocardial infarction when evaluating the effects of different methods of treatment and when comparing results from different centres, several groups of investigators have constructed systems for quantitating the severity of infarction (Schnur, 1953; Peel et al., 1962; Hughes et al., 1963; Gironi, Conte, and Andreola, 1966; Selvini et al., 1967; Shubin et al., 1968; Norris et al., 1969a; Paichl and Sova, 1969). Such a system was designated a 'coronary prognostic index' by Peel et al. (I962). Numerical scores are allotted to the factors believed to be of prognostic significance. The scores are weighted according to the relative contributions of these factors to the mortality rate. Their values may be derived empirically (Schnur, I953; Peel et al., 1962; Gironi et al., 1966), from discriminant analysis (Hughes et al., 1963; Shubin et al., 1968; Norris et al., 1969a), or from

Received I2 July 1972.

${ }^{1}$ Present address: West Middlesex Hospital, Isleworth, Middlesex, England. multiple regression analysis (Selvini et al., 1967; Paichl and Sova, 1969). To calculate the coronary prognostic index for an individual patient, one adds together the scores for any of the factors present in his case. The higher the index (Schnur, I953; Peel et al., 1962; Gironi et al., 1966; Selvini et al., 1967; Shubin et al., 1968; Norris et al., 1969a; Paichl and Sova, 1969) - or the lower (Hughes et al., 1963) the more likely is the patient to die in the early period after infarction.

However, no prognostic index so far published was designed specifically for patients treated in a coronary care unit. Even though the indices of Peel et al. (1962) and of Norris et al. (1969a) have proved useful for cases treated in such units (Lown et al., 1967a; Aber, Portal, and Chopra, 1969; Norris, Brandt, and Lee, 1969b; Thurston, 1969; Linko et al., 1970; Hofvendahl, 1971; Thompson and Sloman, 1971; Royston, 1972; Prakash et al., 1972), there is still a need for an index which is specific for coronary care unit cases. These usually have a lower mortality rate than cases treated in the general wards 
(Marshall, Blount, and Genton, 1968; Rockwell, 1969; Most and Peterson, 1969; Bloomfield et al., 1970; Chapman, 1970; Klaus et al., 1970; Sloman and Brown, 1970; Hofvendahl, 1971). While their mortality rate is lower for virtually every one of numerous factors studied, it is not reduced by the same proportion for all factors (B. L. Chapman, 1972, unpublished observations). Moreover, most of the published indices (Schnur, 1953; Peel et al., 1962; Hughes et al., 1963; Gironi et al., 1966; Selvini et al., 1967; Norris et al., 1969a; Paichl and Sova, 1969) include factors that are not associated with a statistically significant change in the mortality rate of patients treated in a coronary care unit (Chapman, 1971a). These factors are sex (Schnur, 1953; Peel et al., 1962; Hughes et al., 1963; Selvini et al., 1967), previous ischaemic heart disease (Schnur, 1953; Peel et al., 1962; Hughes et al., 1963; Selvini et al., 1967; Norris et al., 1969a), diabetes mellitus (Schnur, 1953; Peel et al., 1962; Hughes et al., 1963; Gironi et al., 1966; Selvini et al., 1967), hypertension (Schnur, 1953; Peel et al., 1962; Hughes et al., 1963; Gironi et al., 1966; Selvini et al., 1967; Paichl and Sova, 1969), and pulmonary infarction (Hughes et al., 1963). The index of Shubin et al. (1968) was intended exclusively for the assessment of cases with cardiogenic shock, and therefore will not be considered further here.

We now present a new and simple coronary prognostic index, designed for patients with acute myocardial infarction treated in a coronary care unit.

\section{Patients and methods}

This is part of a prospective study of patients treated in the coronary care unit of the Royal Newcastle Hospital. The criteria for the diagnosis of acute myocardial infarction and its complications, the treatments used, and the methods and duration of observation have already been described (Chapman, 1970, 1971a). Cardiogenic shock was diagnosed if hypotension (systolic BP $\leqslant 80$ $\mathrm{mmHg}$ ), cyanosis, and coldness of the extremities persisted for more than half an hour after the relief of pain and the administration of oxygen. Oliguria was analysed separately from the syndrome so defined. It consisted of a minimum 24-hour urine volume of $500 \mathrm{ml}$ or less, or, in patients observed for under 24 hours, a flow rate of $0.3 \mathrm{ml}$ or less per minute, measured accurately over at least one hour. The mortality rate refers to the whole time in hospital. The mean time spent in hospital was $22 \cdot I$ days, and the mean time from infarction to death was 8.6 days.

For the SGOT estimations, blood was taken at approximately 24 hours after infarction (Chapman, I97Ib). Many patients had multiple specimens taken, especially if the exact time of infarction was not known, or if reinfarction was suspected. The highest reading was the one analysed. Some patients died before the enzyme was due to be estimated. A few were admitted
TABLE I Factors examined by multiple regression analysis

Personal characteristics: Age, sex, height, weight, ponderal index (Khosla and Lowe, 1967), social class, tobacco consumption.

Past history: Ischaemic heart disease, cardiac failure, chronic renal failure, other diseases.

Admission episode: Month, admission delay, pain duration, dyspnoea, Adams-Stokes attacks, treatment.

Complications and physical signs: Further pain, reinfarction, triple rhythm, cardiac failure, pulmonary oedema, cardiogenic shock, hypotension (systolic, diastolic), Adams-Stokes attacks, mitral incompetence, oliguria, proteinuria, pneumonia, acute bronchitis, pallor, cyanosis (central, peripheral), cold extremities, sweating, pyrexia, newly discovered 'diabetes'.

Arrhythmias and conduction defects: Sinus tachycardia (presence, duration, rate), sinus bradycardia, supraventricular ectopic beats (presence, frequency, origin), supraventricular tachycardia, atrial fibrillation (presence, onset, course), atrial tachycardia with block, ventricular ectopic beats (presence, frequency, foci), ventricular tachycardia, atrioventricular block (first-degree, third-degree), bundlebranch block.

Investigations: Electrocardiogram (definiteness of recent infarction, and depth), serum enzymes (SGOT, LDH), chest $\boldsymbol{x}$-ray (cardiomegaly, pulmonary congestion), polymorph count, erythrocyte sedimentation rate (on admission, after one week), cholesterol, urea, after $50 \mathrm{~g}$ glucose.

too late. In some other cases, specimens were taken at the wrong time, were not taken at all, or proved unsatisfactory for analysis. If an alternative cause for increase was present at the same time, the result was discarded. The time of infarction was taken to be the time of onset of the symptoms of the episode precipitating admission.

A total of more than I 50 factors (including variations) was examined initially, using an NCR 500 computer to sort the data (Chapman, I97Ia). The factors associated with a statistically significant change in the mortality rate were identified with the aid of $\chi^{2}$ tests, and then, along with some other factors important for different reasons, subjected to multiple regression analysis. More than 70 factors were examined in this way (Table $\mathbf{I}$ ). They included personal characteristics and habits, past history, and coexistent disease, details of the episode precipitating admission, cardiac and extracardiac complications, arrhythmias, conduction defects, clinical observations, electrocardiogram, chest $x$-ray, and biochemical and haematological investigations. Because of their large number, these factors were grouped into smaller sets which were analysed in turn, but every factor was correlated with every other factor at least once, and usually several times. Multiple regression analysis was used to quantitate the contribution of each factor to the outcome. The relative degree of association of the individual factors with the outcome was indicated by their partial correlation coefficients. The independence of a particular factor was shown by the departure of its partial correlation coefficient from its simple corre- 
lation coefficient. The overall association of a set of factors with the outcome was defined by the magnitude of the multiple correlation coefficient for that set. The factors that contributed significantly to the outcome were then used in the construction of the coronary prognostic index. Their weighted scores were derived from the regression coefficients of the final multiple regression equation. A CDC 3600 computer was used for these analyses, using the CORE program (Michigan State University). Additional programs were written to permit changes in the scoring of individual factors before each regression analysis, and to maximize the number of patients in each analysis. The statistical procedures and computer techniques will be described more fully elsewhere (Gray and Chapman, 1972).

Finally, the ability of the prognostic index to predict the outcome was tested. The same cases were used for this, as for the index's construction. Each patient's prognostic index was calculated, and then compared with the actual outcome. Mortality rate was correlated with coronary prognostic index. Simple linear correlation and regression analysis were carried out, using methods already referred to (Chapman, I97Ib, 1972). For this, the groups that contained too few cases for percentages to be calculated were combined, but this did not affect the mortality trend.

\section{Results}

Four hundred and ninety-five cases of acute myocardial infarction were treated in the coronary care unit in the 21 months from its establishment in August 1968. Their mortality rate was 17.0 per cent. The final coronary prognostic index was based on 357 cases, and their mortality rate was 16.2 per cent.

Of all the factors examined, only three made significant independent contributions to the outcome. These were the SGOT level, cardiogenic shock, and oliguria. For each, the partial correlation coefficient was highly significant (SGOT, $r=0.180$; shock, $r=0.322$; oliguria, $r=0.329$; for each, $P<0.0005$ ). The multiple correlation coefficient for this set was also highly significant $(R=0.579, P \ll 0.01)$. The coronary prognostic index was therefore based on these factors.

The prognostic scores increased progressively with the SGOT level (Table 2). Shock and oliguria had very high scores which were almost identical. For ease of calculation, a ready-reckoner is provided (Table 3). From this may be read off the prognostic index for any combination of factors. (For simplicity, all values were rounded off to the nearest integer; this accounts for the several minor discrepancies in Tables 2 and 3.)

As the value of the coronary prognostic index rose, so did the mortality rate (Fig.). There was a highly significant linear correlation between the two $(r=0.986, P<0.0002)$. According to the coefficient of determination $\left(r^{2}\right), 97 \cdot 2$ per cent of the
TABLE 2 Coronary prognostic scores

\begin{tabular}{lcc}
\hline Factor & & Score \\
\hline SGOT level* & $\leqslant 40$ & 0 \\
& $41-80$ & 4 \\
& $81-120$ & 7 \\
& $121-160$ & 11 \\
& $161-200$ & 14 \\
& $\geqslant 201$ & 18 \\
Cardiogenic shock & Absent & 0 \\
& Present & 32 \\
Oliguria & & \\
& Absent & 0 \\
& Present & 33 \\
\hline
\end{tabular}

TABLE 3 Ready-reckoner for calculating coronary prognostic index

\begin{tabular}{cllll} 
SGOT level & \multicolumn{4}{l}{ Factors, and corresponding prognostic indices } \\
\cline { 2 - 5 } & SGOT & $\begin{array}{l}\text { SGOT+ } \\
\text { shock }\end{array}$ & $\begin{array}{l}\text { SGOT+ } \\
\text { oliguria }\end{array}$ & $\begin{array}{l}\text { SGOT+ } \\
\text { shock+ } \\
\text { oliguria }\end{array}$ \\
\hline 540 & 0 & 32 & 33 & 65 \\
$4 I-80$ & 4 & 36 & 37 & 69 \\
$81-120$ & 7 & 39 & 40 & 72 \\
$121-160$ & II & 43 & 44 & 76 \\
$161-200$ & 14 & 47 & 47 & 80 \\
$\geqslant 201$ & 18 & 50 & 51 & 83 \\
\hline
\end{tabular}

* In Sigma-Frankel units/ml.

variation in mortality rate was explained by variation in the coronary prognostic index.

Regression analysis (Fig.) showed that an increase in the prognostic index of one was accompanied by an increase in the mortality rate of I per cent $(b=0.986)$. There was little mortality other than that described by the regression coefficient, and hence explained by variation in the prognostic index $(a=I \cdot 122)$. The result was that the numerical values of the prognostic index were close approximations of the observed mortality rate (Table 4). For no value did the index differ by more than about I from the mortality rate, as calculated from the simple regression equation. At the upper end of the range, in fact, the values were identical.

\section{Discussion}

This coronary prognostic index was designed specifically for patients with acute myocardial infarction treated in a coronary care unit. Though many factors were examined during the construc- 
TABLE 4 Comparison of mortality rate ${ }^{\star}$ with values of coronary prognostic index obtained from ready-reckoner†

\begin{tabular}{|c|c|c|c|c|c|c|c|c|c|}
\hline $\begin{array}{l}\text { Prognostic index } \\
\text { Mortality rate }\end{array}$ & $\begin{array}{r}0 \\
I \cdot I\end{array}$ & $\begin{array}{l}4 \\
5 \cdot I\end{array}$ & $\begin{array}{l}7 \\
8 \cdot 0\end{array}$ & $\begin{array}{l}\text { II } \\
12 \cdot 0\end{array}$ & $\begin{array}{l}\text { I4 } \\
14.9\end{array}$ & $\begin{array}{l}18 \\
18 \cdot 9\end{array}$ & $\begin{array}{l}32 \\
32 \cdot 7\end{array}$ & $\begin{array}{l}33 \\
33 \cdot 7\end{array}$ & $\begin{array}{l}36 \\
36 \cdot 6\end{array}$ \\
\hline $\begin{array}{l}\text { Prognostic index } \\
\text { Mortality rate }\end{array}$ & $\begin{array}{l}39 \\
39 \cdot 6\end{array}$ & $\begin{array}{l}40 \\
40 \cdot 6\end{array}$ & $\begin{array}{l}43 \\
43.5\end{array}$ & $\begin{array}{l}44 \\
44 \cdot 5\end{array}$ & $\begin{array}{l}47 \\
47 \cdot 5\end{array}$ & $\begin{array}{l}50 \\
50 \cdot 4\end{array}$ & $\begin{array}{l}51 \\
51 \cdot 4\end{array}$ & $\begin{array}{l}65 \\
65 \cdot 2\end{array}$ & $\begin{array}{l}69 \\
69 \cdot 2\end{array}$ \\
\hline $\begin{array}{l}\text { Prognostic index } \\
\text { Mortality rate }\end{array}$ & $\begin{array}{l}76 \\
76 \cdot I\end{array}$ & $\begin{array}{l}80 \\
80 \cdot 0\end{array}$ & $\begin{array}{l}83 \\
83 \cdot 0\end{array}$ & & & & & & \\
\hline
\end{tabular}

* According to simple regression equation (see Fig.). † See Table 3 .

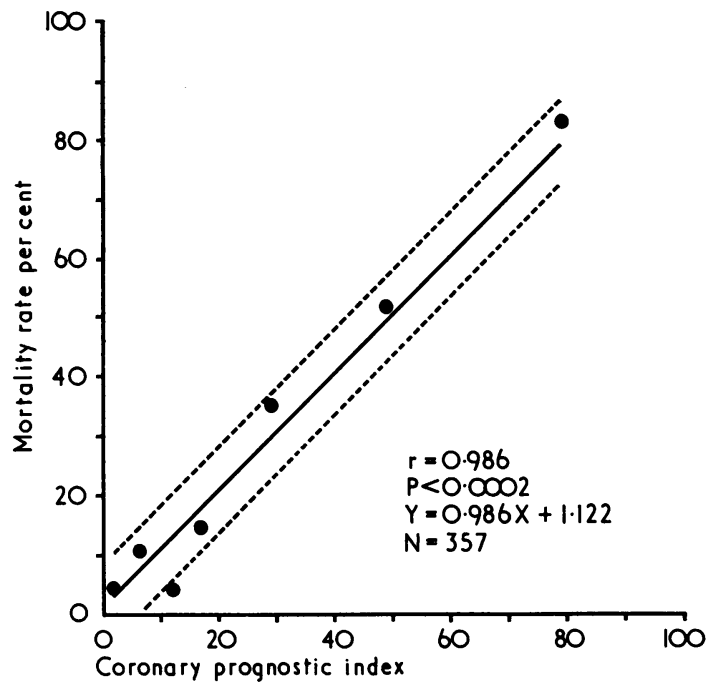

FIG. Linear correlation and regression of mortality rate on coronary prognostic index. The number of patients represented by the points were, from left to right, 155, 55, 44, 33, 14, 39, and 17. The corresponding mortality rates were $3.9,10.9,4.5,15.2,35.7$, $5 \mathrm{I} \cdot 3$, and $82.4 \mathrm{per}$ cent. The distance of each dotted line from the calculated regression line represents twice the standard error of estimate.

tion of the index, this in its final form included only three. These were the SGOT level, cardiogenic shock, and oliguria. The system of scoring was simple, especially with the ready-reckoner provided.

There was very good agreement between the coronary prognostic index and the observed mortality rate. Increasing values of the index were accompanied by a rising mortality rate. There was a highly significant linear correlation between the two. Ninety-seven per cent of the variation in mortality rate was explained by variation in the prognostic index.
This prognostic index could also be used to predict the mortality rate. The numerical values of the index were close approximations of the mortality rate, and never differed by more than about I from its numerical value. This was because there was a mortality rate increase of $\mathrm{I}$ per cent for each prognostic index increase of $\mathrm{I}$, but almost no mortality additional to this. When using the approximation, however, one should take into account the scatter of the mortality rate about the calculated regression line. This is expressed in the standard error of estimate, which was 3.5 per cent.

The results support the hypothesis (Chapman, 1972) that, in cases treated in a coronary care unit, the cardiac complications of acute myocardial infarction are only indirectly related to the mortality rate, their presence merely reflecting the extent of infarction. Many cardiac complications were examined in the course of the multiple regression analyses, but none except cardiogenic shock was found to make a significant independent contribution to the outcome, over and above that made by the SGOT. The height to which this enzyme rises is proportional to the volume of infarcted myocardium (West, Eshchar, and Zimmerman, 1966; Killen and Tinsley, 1966; Kibe and Nilsson, 1967; Whitby, 1968). The hospital mortality rate of acute myocardial infarction increases in a linear fashion with the SGOT level (Chapman, I97Ib). Rising SGOT levels are also accompanied by an increasing incidence of myocardial insufficiency, secondary cardiac arrest, the conduction defects, and all arrhythmias, except sinus bradycardia (Chapman, 1972). The incidence of sinus bradycardia, by contrast, falls as the SGOT level rises (Chapman, 1972). That of primary cardiac arrest does not alter significantly (Chapman, 1972). These trends in incidence are in the same direction as the mortality rates for the corresponding complications. That is, each of the complications whose incidence increases with the SGOT level (Chapman, 1972) is also associated with an increase in the mor- 
tality rate (Chapman, I971a). Sinus bradycardia, on the other hand, is associated with a decrease (Chapman, 1971a), and primary cardiac arrest is associated with no change in mortality (Chapman, 197Ia). It is obvious, however, that in cases not treated in a coronary care unit one or more of these complications makes a contribution to the mortality rate which is over and above that due to its relation to the size of the infarct. It is generally accepted that untreated arrhythmias are responsible for the higher mortality rate of these cases (Mower, Miller, and Nachlas, 1964; Lown et al., 1967a, b; Lawrie, 1969; Lovell and Prineas, 1971). Ventricular fibrillation may complicate infarcts of any severity, whether the criteria for this are clinical (Stock, Goble, and Sloman, 1967; Marshall et al., 1968; Adgey et al., 1969) or biochemical (Chapman, 1972).

Cardiogenic shock was the only cardiac complication to contribute significantly in its own right to the outcome. There is evidence, however, that this complication leads to an extension of the original infarct, presumably because of diminished coronary perfusion (Page et al., 197I). This extension may not necessarily be reflected in the peak enzyme levels. If similar changes occur at the same time in other organs, moreover, there may be an increase in the mortality rate over and above that to be expected from the extent of myocardial necrosis present.

The independent contribution of oliguria to the outcome may be due to such secondary damage in an important extracardiac organ. The incidence of oliguria has a highly significant linear correlation with the SGOT level (B. L. Chapman, I972, unpublished observations). One might, therefore, expect that the oliguria is due to diminished renal perfusion, itself the result of a lowering of the cardiac output which is proportional to the size of the infarct. In keeping with this is the report by Hutton et al. (1970) that all of Io patients with myocardial infarction complicated by acute renal failure had a low cardiac output, hypotension, and renal underperfusion. In only 2 of these patients, however, was the oliguria entirely prerenal. The remaining 8 had varying degrees of 'intrinsic' renal failure. The occurrence of this, nevertheless, was related to the duration of hypotension. Such renal failure, only incompletely related to the fall in cardiac output, may explain the independent contribution of oliguria to the outcome in the present series. The mechanism may be renal cortical ischaemia due to persistent reactive vasoconstriction, such as occurs in acute renal failure from various causes, including shock (Hollenberg et al., 1968). Vasoconstrictors, which may impair tissue perfusion (MacLean et al., 1965), were not used for the treatment of patients in the present series.
It is suggested that the previously published coronary prognostic indices predict the outcome as well as they do, because they include factors which vary with the serum enzyme levels (Chapman, I972; B. L. Chapman, 1972, unpublished observations), and therefore reflect both the extent of infarction (West et al., 1966; Killen and Tinsley, 1966; Kibe and Nilsson, 1967; Whitby, 1968) and the mortality rate (Chapman, I97Ib). These factors are the electrocardiographic depth of infarction (Peel et al., 1962; Selvini et al., I967; Norris et al., 1969a), arrhythmias (Schnur, I953; Peel et al., 1962; Hughes et al., 1963; Gironi et al., 1966; Selvini et al., 1967), conduction defects (Peel et al., 1962; Hughes et al., 1963; Gironi et al., 1966; Selvini et al., 1967; Norris et al., 1969a), myocardial insufficiency (Schnur, 1953; Peel et al., 1962; Hughes et al., 1963; Gironi et al., 1966; Selvini et al., 1967; Paichl and Sova, 1969), hypotension (Hughes et al., 1963; Gironi et al., 1966; Selvini et al., 1967; Norris et al., 1969a), leucocytosis (Hughes et al., I963), increased sedimentation rate (Gironi et al., 1966), pyrexia (Hughes et al., 1963; Selvini et al., 1967), and radiological pulmonary congestion (Norris et al., 1969a), and cardiomegaly (Gironi et al., 1966; Norris et al., 1969a). The incidence of all of these factors varies with the SGOT level (Chapman, I972; B. L. Chapman, I972, unpublished observations). Furthermore, the enzyme levels themselves vary with age (B. L. Chapman, 1972 unpublished observations), a prognostic factor used in all the published indices. There is an inverse linear correlation between the SGOT level and the incidence of obesity (B. L. Chapman, 1972 unpublished observations), a factor that appears in the prognostic index of Gironi et al. (1966), but was excluded from that of Norris et al. (1969a) because, as in the present series, it was found to make no significant independent contribution to the outcome. No previously published coronary prognostic index includes the serum enzyme levels. ${ }^{1}$

It may be objected that the inclusion of the SGOT among the factors used to calculate the index leads to selection of the cases analysed. This enzyme does not reach its maximum level until 24 hours after infarction (West et al., 1966). The mortality rate, even for coronary care unit cases, is highest in the first 24 hours from infarction (Robinson, Sloman, and McRae, 1964; Lawrie et al., 1967; Lown et al., 1967a; MacMillan et al., 1967; Parkinson, Wattie, and Kirk, 1967; Thomas, Jewitt, and Shillingford, I968; Isacsson, Westerlund, and Wingstrand, 1969; Most and Peterson, 1969; Thurston, 1969; Skjaeg-

\footnotetext{
1 In the empirically derived index of Gironi et al. (1966), the scores for the erythrocyte sedimentation rate were weighted more heavily if the serum transaminase level was high.
} 
gestad et al., 1970; Langhorne, 1970; McAllen, I97I). Some patients will, therefore, have died by the time that the index can be calculated. In the present series, however, the cases whose SGOT was estimated constituted a representative sample of the whole series, as judged by the incidence of all other factors associated with a statistically significant change in the mortality rate (B. L. Chapman, 1972, unpublished observations). Furthermore, their mortality rate of 16.2 per cent was not significantly different from the $17 \cdot 0$ per cent for the whole series. Most of the previously published coronary prognostic indices, moreover, have suffered in some way from the (inevitable) failure of their authors to obtain complete information on all patients. Schnur (1953) excluded patients dying in the first 24 hours. Peel et al. (1962) and Hughes et al. (1963) excluded those with incomplete data. The criteria for inclusion in the series of Norris et al. (1969a) included raised serum transaminase levels. They also included evolutionary changes in the electrocardiogram, which may take some time to develop (Parkinson and Bedford, 1928). These authors also substituted certain observations for others, when these were not known (Norris et al., 1969a). While this allowed the inclusion of all cases of infarction in the analysis, it was not established that the substituted factors had the same effect on the mortality rate as those they replaced. Paichl and Sova (1969) accepted only cases with transmural infarcts. Though the prognostic indices of Schnur (1953), Peel et al. (1962), and Norris et al. (1969a) were based on observations made at the time of admission, even these, for reasons mentioned already, were made on selected groups of patients.

We make grateful acknowledgment of the contributions to the project of which this is a part by Dr. J. M. Duggan, Dr. J. T. Holland, Dr. J. N. Walker, Mr. H. M. Frith, Mrs. J. Bubb, and many other staff members of the Royal Newcastle Hospital, the Newcastle Permanent Building Society Limited, and the CSIRO Division of Computing Research. Generous donations of computer facilities and time were made by the two last-mentioned organizations. The Computer Investigation Group of the Hospitals Commission of New South Wales, under Mr. R. B. Thode, also contributed towards the clerical and computer expenses. We are indebted to Mrs. L. Van Aernsbergen and Dr. A. Berkova of the Bibliography Section of the Library of the Royal Society of Medicine, London, for translating the two papers from the Italian and that from the Czechoslovakian, respectively.

\section{References}

Aber, C. P., Portal, R. W., and Chopra, M. P. (1969). Cardiac monitoring in a regional hospital. British Medical fournal, I, 209.
Adgey, A. A. J., Nelson, P. G., Scott, M. E., Geddes, J. S., Allen, J. D., Zaidi, S. A., and Pantridge, J. F. (I969). Management of ventricular fibrillation outside hospital. Lancet, 1, I 169.

Bloomfield, D. K., Slivka, J., Vossler, S., and Edelstein, J. (1970). Survival in acute myocardial infarction before and after the establishment of a coronary care unit. Chest, 57, 224.

Chapman, B. L. (1970). Hospital mortality of myocardial infarction, before and after coronary care. Medical fournal of Australia, 1, 833.

Chapman, B. L. (1971a). Prognostic factors in acute myocardial infarction treated in a coronary care unit. Australian and New Zealand Fournal of Medicine, $\mathbf{1}, 53$.

Chapman, B. L. (197Ib). Correlation of mortality rate and serum enzymes in myocardial infarction. 'Test of efficiency of coronary care. British Heart fournal, 33, 643.

Chapman, B. L. (1972). Relation of cardiac complications to SGOT level in acute myocardial infarction. British Heart Fournal, 34, 890.

Gironi, G., Conte, G., and Andreola, F. (1966). La prognosi dell'infarto miocardico: presentazione di uno schema di quantizzazione studiato su 100 casi. Minerva Cardioangiologica, 14, 363.

Gray, C. H., and Chapman, B. L. (1972). Construction of a prognostic index for acute myocardial infarction treated in a coronary care unit. In preparation.

Hofvendahl, S. (197I). Influence of treatment in a coronary care unit on prognosis in acute myocardial infarction. A controlled study in 271 cases. Acta Medica Scandinavica, 189, Suppl. 519.

Hollenberg, N. K., Epstein, M., Rosen, S. M., Basch, R. I., Oken, D. E., and Merrill, J. P. (1968). Acute oliguric renal failure in man: evidence for preferential renal cortical ischemia. Medicine, 47, 455.

Hughes, W. L., Kalbfleisch, J. M., Brandt, E. N., and Costiloe, J. P. (1963). Myocardial infarction prognosis by discriminant analysis. Archives of Internal Medicine, III, 338.

Hutton, I., Pack, A. I., Lindsay, R. M., and Lawrie, T. D. V. (1970). Clinical significance of renal haemodynamics in acute myocardial infarction. Lancet, $2,123$.

Isacsson, S.-O., Westerlund, A., and Wingstrand, H. (1969). A review of 191 patients with myocardial infarction treated in a Swedish coronary care unit. Acta Medica Scandinavica, $185,545$.

Khosla, T., and Lowe, C. R. (1967). Indices of obesity derived from body weight and height. British fournal of Preventive and Social Medicine, 21, 122.

Kibe, O., and Nilsson, N. J. (1967). Observations on the diagnostic and prognostic value of some enzyme tests in myocardial infarction. Acta Medica Scandinavica, 182, 597.

Killen, D. A., and Tinsley, E. A. (1966). Serum enzymes in experimental myocardial infarcts. Archives of Surgery, 92, 418.

Klaus, A. P., Sarachek, N. S., Greenberg, D., Pekover, J., and Cooper, J. K. (1970). Evaluating coronary care units. American Heart fournal, 79, 471.

Langhorne, W. H. (1970). The coronary care unit revisited. Three years' experience in a community hospital. Chest, $57,550$.

Lawrie, D. M. (1969). Ventricular fibrillation in acute myocardial infarction. American Heart fournal, 78, 424.

Lawrie, D. M., Greenwood, T. W., Goddard, M., Harvey, A. C., Donald, K. W., Julian, D. G., and Oliver, M. F. (1967). A coronary-care unit in the routine management of acute myocardial infarction. Lancet, 2, 109.

Linko, E., Koskinen, P. J., Ruosteenoja, R., Kauranen, O., and Hakala, T. (1970). Intensive care of myocardial infarction. A two-year experience with 329 patients. Acta Medica Scandinavica, 187, 117. 
Lovell, R. R. H., and Prineas, R. J. (197I). Mechanisms of sudden death and their implications for prevention and management. Progress in Cardiovascular Diseases, 13, 482.

Lown, B., Fakhro, A. M., Hood, W. B., and Thorn, G. W. (I967a). The coronary care unit. New perspectives and directions. Fournal of the American Medical Association, 199, 188.

Lown, B., Vassaux, C., Hood, W. B., Fakhro, A. M., Kaplinsky, E., and Roberge, G. (1967b). Unresolved problems in coronary care. American fournal of Cardiology, 20, 494.

McAllen, P. M. (197I). Experiences of coronary intensive care in a district hospital. Postgraduate Medical fournal, 47, 5 .

MacLean, L. D., Duff, J. H., Scott, H. M., and Peretz, D. I. (1965). Treatment of shock in man based on hemodynamic diagnosis. Surgery, Gynecology and Obstetrics, 120, I.

MacMillan, R. L., Brown, K. W. G., Peckham, G. B., Kahn, O., Hutchison, D. B., and Paton, M. (1967). Changing perspectives in coronary care. A five year study. American fournal of Cardiology, 20, $45 \mathrm{I}$.

Marshall, R. M., Blount, S. G., and Genton, E. (1968). Acute myocardial infarction. Influence of a coronary care unit. Archives of Internal Medicine, 122, 472.

Michigan State University (Computer Laboratory). Statistical package. CORE correlation and regression program. Calculation of more than one regression from a set of data.

Most, A. S., and Peterson, D. R. (1969). Myocardial infarction surveillance in a metropolitan community. Fournal of the American Medical Association, 208, 2433.

Mower, M. M., Miller, D. I., and Nachlas, M. M. (1964). Clinical features relevant to possible resuscitation in death after myocardial infarction. American Heart fournal, 67, 437.

Norris, R. M., Brandt, P. W. T., Caughey, D. E., Lee, A. J., and Scott, P. J. (1969a). A new coronary prognostic index. Lancet, $\mathbf{I}, 274$.

Norris, R. M., Brandt, P. W. T., and Lee, A. J. (1969b). Mortality in a coronary-care unit analysed by a new coronary prognostic index. Lancet, $\mathbf{I}, 278$.

Page, D. L., Caulfield, J. B., Kastor, J. A., DeSanctis, R. W. and Sanders, C. A. (197I). Myocardial changes associated with cardiogenic shock. New England fournal of Medicine, 285, 133 .

Paichl, P., and Sova, J. (1969). Prognostic index in acute myocardial infarction. Casopis Lékar̆u Českých, 108, 1420.

Parkinson, J., and Bedford, D. E. (1928). Successive changes in the electrocardiogram after cardiac infarction (coronary thrombosis). Heart, 14, 195.

Parkinson, P. I., Wattie, W. J., and Kirk, G. M. (1967). The coronary care unit at Palmerston North Hospital. New Zealand Medical fournal, 66, 872.

Peel, A. A. F., Semple, T., Wang, I., Lancaster, W. M., and Dall, J. L. G. (1962). A coronary prognostic index for grading the severity of infarction. British Heart fournal, 24, 745 .

Prakash, R., Parmley, W. W., Horvat, M., and Swan, H. J. C. (1972). Serum cortisol, plasma free fatty acids, and urinary catecholamines as indicators of complications in acute myocardial infarction. Circulation, 45, 736.
Robinson, J. S., Sloman, G., and McRae, C. (1964). Continuous electrocardiographic monitoring in the early stages after acute myocardial infarction. Medical fournal of Australia, 1, 427.

Rockwell, M. A. (1969). A summary of coronary-care-unit literature. Rand Corporation Memorandum RM-5944R.C.

Royston, G. R. (1972). Short stay hospital treatment and rapid rehabilitation of cases of myocardial infarction in a district hospital. British Heart fournal, 34, 526.

Schnur, S. (1953). Mortality rates in acute myocardial infarction. II. A proposed method for measuring quantitatively severity of illness on admission to the hospital. Annals of Internal Medicine, 39, 1018.

Selvini, A., Ricci, F., Gironi, G., and Giudice, N. (1967). Presentazione di un indice prognostico discriminatorio nell' infarto miocardico calcolato su 168 pazienti mediante elaboratore elettronico. Minerva Medica, 58, 4113.

Shubin, H., Afif, A. A., Rand, W. M., and Weil, M. H. (1968). Objective index of haemodynamic status for quantitation of severity and prognosis of shock complicating myocardial infarction. Cardiovascular Research, 2, 329.

Skjaeggestad, O., Grendahl, H., Hjermann, I., and Sivertssen, E. (1970). One year's experience of medical intensive care units. Acta Medica Scandinavica, 187, 275.

Sloman, G., and Brown, R. (1970). Hospital registration in patients with acute myocardial infarction. American Heart Fournal, 79, 76r.

Stock, E., Goble, A., and Sloman, G. (1967). Assessment of arrhythmias in myocardial infarction. British Medical fournal, 2, 719.

Thomas, M., Jewitt, D. E., and Shillingford, J. P. (1968). Analysis of 150 patients with acute myocardial infarction admitted to an intensive care and study unit. British Medical fournal, 1, 787.

Thompson, P., and Sloman, G. (197I). Sudden death in hospital after discharge from coronary care unit. British Medical fournal, $4,136$.

Thurston, J. G. B. (1969). The Westminster Hospital coronary unit - experience with 260 patients admitted consecutively with a diagnosis of acute myocardial infarction. Postgraduate Medical fournal, 45, I63.

West, M., Eshchar, J., and Zimmerman, H. J. (1966). Serum enzymology in the diagnosis of myocardial infarction and related cardiovascular conditions. Medical Clinics of North America, 50, I7I.

Whitby, G. (1968). The enzyme response of the myocardium to ischaemia and infarction. In Acute Myocardial Infarction: Proceedings of a Symposium, University of Edinburgh, 1967 , p. 266. Ed. by D. G. Julian and M. F. Oliver, Livingstone, Edinburgh and London.

Requests for reprints to Dr. B. L. Chapman, The West Middlesex Hospital, Isleworth, Middlesex. 